\title{
Credit Information Sharing and Its Link to Financial Inclusion and Financial Intermediation
}

\section{Christof Morscher}

Research Associate, Department of Investment and Finance, Technische Universität Bergakademie Freiberg, Germany

\section{Andreas Horsch}

Professor, Department of Investment and Finance, Technische Universität Bergakademie Freiberg, Germany

\section{Johannes Stephan}

Professor, Department of Economics, Technische Universität Bergakademie Freiberg, Germany

\begin{abstract}
In this article, several regression analyses are conducted to analyse the relationship of credit information sharing (by both private credit bureaus and public credit registries) with financial inclusion and financial intermediation. We find that there is a positive relationship between information sharing mechanisms and financial inclusion (measured by account (at a financial institution), borrowed from a financial institution, and domestic credit). We do not find significant results for bank performance parameters. Whereas this is the case with bank non-performing loans, the data do not allow (due to low $\mathrm{R}^{2}$ ) drawing conclusions on other parameters such as lending minus inflation rate or bank concentration.
\end{abstract}

Keywords: asymmetric information; (consumer) credit information system(s); credit information sharing; credit bureaus; credit registry; financial inclusion; financial intermediation.

JEL Classification: C33, D82, E51, G21.

(C) The Authors, 2017. This article is published with open access at ARMG Publishing.

\section{Introduction}

The focus of this article is on the economic effects of private credit bureaus (PCB) and public credit registries (PCR), especially on financial inclusion and on financial intermediation. Those institutions are part of a specific (national and international) credit reporting system, comprising additionally other institutions, individuals, culture, legal and regulating frameworks, technology, procedures and standards. The objective of this system is to collect and combine information (in a database) on (potential) borrowers. This information can be relevant for the efficiency of the credit providing decision-making process (cp. World Bank, 2012, p. 5; Miller, 2003, pp. 27-28). Historically, the first public credit registry was introduced after the Great Depression, 1934 in Germany and several others in Europe after the Second World War (for a longer and more in-depth introduction e.g. Schmieder, 2006, pp. 653-654). Especially since 2001, when the International Finance Corporation (IFC), which is part of the World Bank Group, set up the Global Credit Reporting Program (first introduced as Global Credit Bureau Program and later renamed to its current name to reflect the change of scope with both private credit bureaus and public credit register), more information about these entities seems to exist, while considerable progress in this sector, in terms of newly established registries/bureaus was observable since then (World Bank - International Finance Corporation, 2015). This can be easily seen in the increase of the total amount of public credit registers and private credit bureaus. While in the year 2004 a total of 49 economies had a private credit bureau ( 22 for public credit registry) with a coverage of at least $5 \%$ of the adult population out of 145 observed ones, this number was already up to 94 (58) out of 189 economies in 2014 (World Bank - International Finance Corporation, 2014, p. 72). Based on the latest available data from 2016, 38 countries do have both, a credit bureau and a credit registry, 108 have only a credit bureau, 93 have only a credit registry and 27 have neither (measured based on the latest Doing Business dataset of the World Bank, if coverage rate by credit bureau or credit register was higher than zero, the presence of such an entity was counted, cp. World Bank, 2017).

As credit is often praised as the lifeblood of an economy (e.g. Cork, 1982, p. 10: „Credit is the lifeblood of the modern industrialised economy."), it is obvious that it is of utmost importance for an economy or an 
economically integrated region, to have a healthy, sound and sustainable credit market. However, as PCB/PCR may decrease the asymmetric information between a potential debtor and a creditor, they may have a positive impact on financial inclusion, too. Next to that we also test for the impact of such systems on various indicators of bank performance.

This article starts with the background and (possible) associated problems arising in a creditor/debtor relationship and an overview of the literature in this context. Next, we discuss our hypotheses, methodology and data used before we present our empirical results and finish with our concluding remarks.

\section{Literature review}

Asymmetric information in a market may lead to unwanted effects such as adverse selection (Akerlof, 1970; Ausubel, 1999) or credit rationing (Jaffee/Russell, 1976; Stiglitz/Weiss, 1981). Credit information sharing presents a solution to reduce these effects and mitigate moral hazard as well; as shown by Klein (1992) in a game theory model, credit reporting promotes morality by borrowers. Pagano and Jappelli (1993) showed in their model with adverse selection, among other results, that the incentive to share information for the lenders increases with the mobility and heterogeneity of the borrowers as well as with the size of the credit market. However, the fear of potential market entrants reduces these incentives. This all suggests that with information about the borrowers being shared, the pool of borrowers should improve, the risks of defaults should be reduced, and in some circumstances, the volume of lending should increase. Similarly, as shown in the model of Padilla and Pagano (1997), default rates are lower when information sharing takes place, interest rates are predicted to decrease and the total volume of lending to increase. In line with that, Bennardo et al. (2015) also show in their theoretical work that information sharing reduces default and interest rates. Next to that, credit access improves, at least where the value of collateral is not very volatile. The model of McIntosh and Wydick (2009) decomposes the overall effect of credit information sharing into three: a screening effect, an incentive effect with lower borrower default rates, and a credit expansion effect which increases default rates from larger loans (even though the former seem to overwhelm the latter in an overall view). In another model, Padilla and Pagano (2000) show that the disciplinary effect on borrowers from sharing information between lending institutions reduces default and interest rates. However, they show that this depends also on the type of information that is shared. Sharing more than default information may reduce borrower's incentive to perform well. Similarly, Vercammen (1995) discusses the optimal length of time that information of a borrower's credit report should be kept in the records. He shows that excessively long credit histories may have negative welfare impacts. McIntosh and Wydick (2005) are in favor of adding credit bureaus to the microfinance lending system, because more competition between micro-finance institutions is expected to result in higher information asymmetries and hence a worsening outcome for all borrowers. Finally, Brown and Zehnder (2010) find that on the one hand, asymmetric information in credit markets increases the frequency of information sharing, whereas on the other, stronger competition between lenders tends to have the opposite effect.

Besides the aforementioned theoretical papers, several empirical findings exist on the subject. Bruhn et al. (2013) studied the emergence of credit reporting institutions and find that countries with lower entry barriers into the credit market are less likely to have a credit bureau. The same can be found in countries, where bank concentration is high. However, where banks participation in information sharing with a credit registry is mandatory, they also find no significant results on bank competition or concentration. Love and Mylenko (2003) focus on the effect of information sharing for businesses. While they find that the existence of credit bureaus is linked to lower financing constraints (as perceived by managers) as well as a higher share of bank financing, they find no significant results for the former with credit registries. Stronger rule of law seems to have an additional important positive effect on the effectiveness of credit bureaus. Brown et al. (2009) who also focus on firms find that information sharing is associated with both improved availability and lower cost of credit to them and even more so in countries with weak legal environments. In a more recent paper, Peria and Singh (2014) are able to find a significant impact on corporate finance by credit bureaus, but not by credit registry. The introduction of a credit bureau increases the likelihood of access to finance for firms and results in a drop of interest rates, amongst other aspects. These effects are more pronounced the higher the coverage rate and scope as well as accessibility of credit bureaus, and the weaker national contract enforcement is. Luoto et al. (2007) focus on the microfinance credit market in Guatemala and find that credit information systems can improve lending performance. Similarly, de Janvry et al. (2010), who also focus on the Guatemalan microfinance sector, found that a reduction in information asymmetry resulted in efficiency gains for the lender, which were augmented when borrowers understood how the system worked. On the other hand, 
Behr and Sonnekalb (2012) concentrate on the effects of the introduction of a credit registry in Albania. They cannot find evidence that access to or cost of credit are affected but that loan performances improves. This is especially the case for repeat borrowers, and where competition is weak and borrowers are concerned about future access to credit. Gietzen (2016) analyses empirical data on the impact of the introduction of credit information sharing in an African banking market. He finds support that adverse selection problems are mitigated. Repeating borrowers enjoy reduced interest rates and customers who switch institutions tend to profit from this. On the other hand, first time loans tend to become pricier, as banks have less capacity to hold good borrowers, but this effect is outweighed with the reduction in costs for follow-up loans.

We also find papers which focus on the effect of information sharing by cross country analysis. Fosu (2014) focuses on African countries and finds that credit information sharing increases bank lending, whereas this effect is moderated by bank market concentration. In an early attempt, Jappelli and Pagano (2002) find that both bank lending is higher and credit risk is lower in countries who do have an information sharing mechanism among lenders (regardless whether a public or private one). Djankov et al. (2007) investigate 129 countries and the effect of legal creditor rights as well as credit bureaus and registers on private credits. Both information sharing and legal rights have a positive impact on private credit to GDP. Houston et al. (2010), who analyze 69 countries, find among other things that credit information sharing leads to higher bank profitability, lower bank risk, as well as to a reduced likelihood of financial crisis and higher economic growth on a macroeconomic level. Büyükkarabacak and Valev (2012) find that credit information sharing (especially) reduces the likelihood of banking crisis (in low income countries). Giannetti and Jentzsch (2013), who analyze 172 countries from the year 2000 to 2008 conduct a difference-in-difference analysis, where they focus on the introduction of a national identification system and the interplay with credit reporting on financial intermediation (bank credit to deposits, net interest margin) and -inclusion (private credit to GDP). They find slightly positive effects on both, where developed credit reporting systems exist. Similarly, Nana (2014) checks for the effect of legal systems and information-sharing and finds that the former is associated with better contract enforceability, whereas the latter with higher private credit to GDP.

\section{Research hypotheses}

The theoretical discussion as well as the review of the empirical literature raises a number of questions that we are trying to follow in this paper on the effect of the institution of credit reporting systems on particular features of the financial sector. We formulate these questions in a number of hypotheses outlined below, whereby we distinguish broadly between two main areas: the first one is about financial inclusion and the second one about banking related effects.

H1: Credit reporting systems have a positive effect on financial inclusion.

H1a: Credit reporting systems have a positive effect on the share of the population with an account (at a financial institution)

H1b: Similarly, the share of those, who borrow from a financial system increases, resp. credit information sharing has a positive effect on the borrowing rate

H1c: The overall rate of domestic credit to the private sector increases with the coverage of credit information systems

H2: Credit reporting systems have effects on the banking-sector

H2a: Credit information sharing has a negative effect on non-performing loans

$\mathrm{H} 2 \mathrm{~b}$ : Credit information sharing decreases the lending minus inflation rate

H2c: Credit information sharing decreases banking concentration and has a positive effect on the stability of the banking system

\section{Data and methodology}

We retrieved country-level data mainly from a number of data bases of the World Bank and added some information from the International Monetary Fund and the Heritage Foundation. To test our hypotheses, we tested several (panel) models by use of linear OLS regressions (a detailed summary and description of the variables used can be found in the appendix). 
Due to the fact that our database is unbalanced, the Levin-Lin-Chu and Hadri Lagrange multiplier stationary test could not test for unit roots. We find variance inflation factors below 3 and thus conclude to have no problem with multicollinearity. Additionally, we conducted a pairwise correlation calculation of all independent variables (legal origin - scan is omitted in the regressions and thus excluded) and in fact, no coefficient turns out to be higher than 0.65 .

Table 1. Correlation matrix of the independent variables

\begin{tabular}{|c|c|c|c|c|c|c|c|c|c|c|c|c|}
\hline & \begin{tabular}{|l|} 
PCR \\
coverage
\end{tabular} & $\begin{array}{l}\mathrm{PCB} \\
\text { coverage }\end{array}$ & BranchesCB & Unemployment & IOEF & Popdensity & $\begin{array}{l}\text { GDP } \\
\text { per } \\
\text { capita } \\
\end{array}$ & \begin{tabular}{|l} 
GDP \\
growth
\end{tabular} & eng & french & ger & soc \\
\hline PCR coverage & 1 & & & & & & & & & & & \\
\hline \begin{tabular}{|l|} 
PCB coverage \\
\end{tabular} & -0.06 & 1 & & & & & & & & & & \\
\hline BranchesCB & 0.23 & 0.29 & 1 & & & & & & & & & \\
\hline Unemployment & 0.13 & 0.04 & 0.15 & 1 & & & & & & & & \\
\hline IOEF & 0.09 & 0.49 & 0.37 & -0.02 & 1 & & & & & & & \\
\hline Popdensity & -0.06 & 0.10 & 0.00 & -0.13 & 0.32 & 1 & & & & & & \\
\hline GDP per capita & 0.00 & 0.42 & 0.37 & -0.12 & 0.64 & 0.18 & 1 & & & & & \\
\hline GDP growth & 0.01 & -0.06 & -0.07 & -0.25 & 0.03 & 0.03 & -0.10 & 1 & & & & \\
\hline eng & -0.29 & 0.02 & -0.17 & 0.00 & 0.06 & 0.19 & -0.03 & 0.10 & 1 & & & \\
\hline french & 0.25 & -0.24 & 0.02 & -0.06 & -0.21 & -0.10 & -0.15 & -0.08 & -0.63 & 1 & & \\
\hline ger & 0.06 & 0.30 & 0.18 & 0.17 & 0.23 & -0.04 & 0.16 & -0.05 & -0.24 & -0.34 & 1 & \\
\hline soc & 0.03 & -0.06 & 0.01 & -0.03 & -0.12 & -0.06 & -0.14 & 0.08 & -0.19 & -0.27 & -0.10 & 1 \\
\hline
\end{tabular}

To decide which type of regression model to use with the panel data over years and countries (simple OLS or fixed vs. random effects model), we conducted several pre-tests. Whereas the Breusch-Pagan Lagrange multiplier test significantly indicates that a pooled regression without considering effects is not appropriate, the Hausman test shows significant results for a fixed-effect model, as expected for such country-level data. The Breusch-Pagan LM test of independence could not be conducted because of too few common observations across the panel. Because we find significant results when testing for time-fixed effects, we add them in our models. Additionally, the Breusch-Pagan test establishes heteroskedasticy, so that we use robust heteroscedasticity-consistent standard errors (Huber/White estimators, cp. White, 1980). When conducting the Wooldridge-test, we do find serial correlation, but as the panel consists only of a limited time span, far below 20-30 years, this should not to be a problem for our test models.

\section{Empirical results}

The following part presents the results of our empirical analysis. In accordance with the list of hypotheses, we start with the various results related to financial inclusion (H1) and then turn to the results of the set of sub hypotheses for the banking sector (H2).

\subsection{Financial inclusion}

In order to participate and take full advantage of the financial system, it is especially necessary, first, to have access to an account (at a financial institution). Other signs of financial inclusion, such as the fraction of the population that has actually borrowed from a financial institution, as well as the amount of domestic credit extended to the private sector (by banks), provide even more insights into this. Therefore, we analyze the way that a number of relevant parameters are connected to financial inclusion (we do not want to use existing methods to fill up missing values (cp. e.g. Liu, 2016, pp. 441-473), as this could be done in different ways. Therefore, we show results with the data at hand only).

\subsubsection{Account (at a financial institution)}

For this dependent variable and the next one, data is only available for the years of 2011 and 2014. As a panel regression using only those two years would be not fruitful, we treat both years as equal in time and estimate a cross-sectional model by using the means of both years for each variable (where information for one year was missing, we used the data for the available year). The following table shows the regression outcomes with the dependent variable 'Account' denoting the share of the population that has access to an account of any kind (we also tested by use of the variable 'Account at a financial institution', which does not include the group of mobile money accounts and found similar statistical significant results - both sets of data differ only slightly and only for some countries). 
Dependent Variable: Account

Number of obs $=142$, R-squared $=0.7748$, Adj R-squared $=0.7538$

Table 2. Results of the regression with the dependent variable Account

\begin{tabular}{|c|c|c|c|c|c|c|}
\hline Variable & Coef. & Std. Err. & $\mathrm{t}$ & \multicolumn{2}{|c|}{ P>ItI } & \multicolumn{2}{|c|}{ [95\% Conf. Interval] } \\
\hline PCR coverage & .3406079 & .075199 & 4.53 & 0.000 & .1918248 & .489391 \\
\hline PCB coverage & .1244575 & .0434147 & 2.87 & 0.005 & .0385605 & .2103544 \\
\hline BranchesCB & .2329686 & .0758198 & 3.07 & 0.003 & .0829572 & .38298 \\
\hline Unemployment & -.1494961 & .2440592 & -0.61 & 0.541 & -.6323733 & .3333811 \\
\hline IOEF & .1922842 & .1875785 & 1.03 & 0.307 & -.1788445 & .5634129 \\
\hline Popdensity & .0020737 & .0016784 & 1.24 & 0.219 & -.0012471 & .0053945 \\
\hline GDP per capita & .000763 & .0001019 & 7.49 & 0.000 & .0005615 & .0009646 \\
\hline GDP growth & -.8391331 & .5636096 & -1.49 & 0.139 & -1.954248 & .2759823 \\
\hline eng & -1.118506 & 9.063438 & -0.12 & 0.902 & -19.05074 & 16.81373 \\
\hline french & -19.07975 & 9.106617 & -2.10 & 0.038 & -37.09741 & -1.062083 \\
\hline ger & 8.787441 & 9.357131 & 0.94 & 0.349 & -9.725872 & 27.30075 \\
\hline soc & -11.18597 & 10.19619 & -1.10 & 0.275 & -31.35939 & 8.987436 \\
\hline cons & 29.33757 & 14.08204 & 2.08 & 0.039 & 1.475921 & 57.19922 \\
\hline
\end{tabular}

We find significant results (at least at the 1\% level) for both PCB and PCR coverage, as well as for BranchesCB and GDP per capita. This lends support to our hypothesis that the quality of the institution of a credit reporting system (measured as the extent of coverage in the population) does in fact have a positive effect on the share of the population with an account (at a financial institution), our first measure of financial inclusion. The variable legal origin (french) and the constant are both significant on a $5 \%$ level significant.

\subsubsection{Borrowed from a financial institution}

In the following, the results of the cross-sectional regression with the dependent variable 'borrowed from a financial institution' are summarized. Like before, we also have a relatively high $\mathrm{R}^{2}$ here.

Dependent Variable: BorrowedFI

Number of obs $=142, \mathrm{R}$-squared $=0.5052$, Adj R-squared $=0.4592$

Table 3. Results of the regression with the dependent variable BorrowedFI

\begin{tabular}{|l|c|c|c|c|c|c|}
\hline \multicolumn{1}{|c|}{ Variable } & Coef. & Std. Err. & $\mathrm{t}$ & \multicolumn{2}{c|}{$\mathrm{P}>\mathrm{ItI}$} & \multicolumn{2}{c|}{ [95\% Conf. Interval] } \\
\hline PCR coverage & .0850114 & .023425 & 3.63 & 0.000 & .0386644 & .1313583 \\
\hline PCB coverage & .0524475 & .013524 & 3.88 & 0.000 & .02569 & .079205 \\
\hline BranchesCB & .0472294 & .0236184 & 2.00 & 0.048 & .0004999 & .093959 \\
\hline Unemployment & -.096858 & .0760261 & -1.27 & 0.205 & -.2472775 & .0535616 \\
\hline IOEF & .1095887 & .058432 & 1.88 & 0.063 & -.0060204 & .2251978 \\
\hline Popdensity & -.0010249 & .0005228 & -1.96 & 0.052 & -.0020593 & $9.57 \mathrm{e}-06$ \\
\hline GDP per capita & .0000473 & .0000317 & 1.49 & 0.139 & -.0000155 & .0001101 \\
\hline GDP growth & .3715591 & .1755682 & 2.12 & 0.036 & .024193 & .7189251 \\
\hline eng & -8.30485 & 2.823323 & -2.94 & 0.004 & -13.89086 & -2.718836 \\
\hline french & -11.49603 & 2.836774 & -4.05 & 0.000 & -17.10865 & -5.883403 \\
\hline ger & -11.36142 & 2.91481 & -3.90 & 0.000 & -17.12844 & -5.594394 \\
\hline soc & -6.711119 & 3.176183 & -2.11 & 0.037 & -12.99527 & -.4269632 \\
\hline cons & 9.716388 & 4.38665 & 2.21 & 0.029 & 1.037293 & 18.39548 \\
\hline
\end{tabular}

Similar to the previous regression, we find consistent results and that both PCB and PCR coverage are significant at a $1 \%$ level. Due to missing values, there is much less data for our second regression with the dependent variable 'BorrowersCB' (we hence do not report the results in full in a table). We find some differences between the above results related to 'BorrowedFI' and the one for 'BorrowersCB': whereas the variable BranchesCB is significant at a 5\% level for 'BorrowedFI' (see above table), it is not significant in the second model specification. The IOEF is significant on a $10 \%$ level in the 'BorrowedFI' version and even at a $5 \%$ 
level in the second regression. Similarly, Popdensity is significant on a $10 \%$ level above, but at a $1 \%$ in the second regression. Whereas GDP per capita is not significant in the 'BorrowedFI' regression, but GDP growth is at a $5 \%$ level, it is the opposite in the second regression, where the former is significant at a $10 \%$ level significant but not GDO growth. Finally, the legal origin variables eng and french are significant in both regressions at a $1 \%$ level, but whereas this is also the case for ger in the 'BorrowedFI' model specification, the variable is omitted by the statistical programme in the second one. Soc variable and the constant term are significant at the 5\% level in the above presented regression, but not in the second one on 'BorrowersCB'.

In toto, we are able to present two different test model specifications which both produce comparable results, and both of which are unambiguous with regard to the hypothesis H1b: The share of the population that is able to access the credit market by borrowing money from financial institutions or a commercial bank clearly increases with increasing coverage of the credit reporting systems.

\subsubsection{Domestic credit to private sector of GDP}

In contrast to the two previous regressions, we have sufficient data for the following hypotheses tests to use a panel structure over time, ranging from 2005 to 2014. The results are presented in Table 4:

Dependent Variable: DcreditPS

Number of obs $=1,110$, Number of groups $=137, \mathrm{R}$-squared - overall $=0.5588$

Table 4. Results of the panel-regression with the dependent variable DcreditPS

\begin{tabular}{|l|c|c|c|c|c|c|}
\hline \multicolumn{1}{|c|}{ Variable } & Coef. & $\begin{array}{c}\text { Robust } \\
\text { Std. Err. }\end{array}$ & $\mathrm{t}$ & $\mathrm{T}$ & \multicolumn{2}{c|}{ [95\% Conf. Interval] } \\
\hline PCR coverage & .0856921 & .087232 & 0.98 & 0.328 & -.0868146 & .2581987 \\
\hline PCB coverage & .0680084 & .0374235 & 1.82 & 0.071 & -.0059988 & .1420156 \\
\hline Unemployment & -.5245089 & .3784394 & -1.39 & 0.168 & -1.272896 & .2238779 \\
\hline LMI & .0244668 & .1173468 & 0.21 & 0.835 & -.2075935 & .2565272 \\
\hline IOEF & .3785816 & .2608219 & 1.45 & 0.149 & -.1372095 & .8943728 \\
\hline BranchesCB & .2341958 & .2392492 & 0.98 & 0.329 & -.238934 & .7073257 \\
\hline GDP per capita & .0007809 & .0010226 & 0.76 & 0.446 & -.0012414 & .0028032 \\
\hline GDP growth & -.2082091 & .1182598 & -1.76 & 0.081 & -.4420751 & .0256569 \\
\hline time & & & & & & .4447387 \\
\hline 2006 & 2.152735 & .8636886 & 2.49 & 0.014 & .5789062 & 3.860732 \\
\hline 2007 & 3.256014 & 1.353742 & 2.41 & 0.018 & .7416152 & 7.529597 \\
\hline 2008 & 4.135606 & 1.716251 & 2.41 & 0.017 & 2.073121 \\
\hline 2009 & 5.680623 & 1.824191 & 3.11 & 0.002 & 2.073175 & 9.288071 \\
\hline 2010 & 6.071192 & 2.040933 & 2.97 & 0.003 & 2.035123 & 10.10726 \\
\hline 2011 & 4.906175 & 2.14865 & 2.28 & 0.024 & .6570891 & 9.155261 \\
\hline 2012 & 4.783007 & 2.430961 & 1.97 & 0.051 & -.0243653 & 9.590379 \\
\hline 2013 & 5.965884 & 2.782514 & 2.14 & 0.034 & .4632939 & 11.46847 \\
\hline 2014 & 6.603525 & 3.457859 & 1.91 & 0.058 & -.234601 & 13.44165 \\
\hline cons & 13.24141 & 17.12692 & 0.77 & 0.441 & -279.7876 & 47.11094 \\
\hline
\end{tabular}

Again, we test different model specifications with the two alternative dependent variables 'DcreditPS' and 'DcreditbyB'. We find very similar results between those specifications: for both, there are significant (10\% level) results for PCB coverage and GDP growth. This again suggests that the coverage of a credit reporting system (here only the private sector variant turns out to be significant, for the public, we cannot tell with $\mathrm{H} 0$ not being rejected) does produce a larger overall rate of domestic credit to the private sector (H1c). In contrast to the above presented results for 'DcreditPS', the IOEF turns out to be significant (at the $10 \%$ level) in the second regression on 'DcreditbyB'.

\subsection{Financial intermediation}

In contrast to the previous subchapter, we do not find such clear and significant results in the following panel regressions. Because we only get results with very low $\mathrm{R}^{2}$ for two of the three regression tests, and because the results for most independent variables turned out to be non-significant as well, we decided to not publish 
the results of the models for $\mathrm{H} 2 \mathrm{~b}$ (effect on the deflated lending rate) and for $\mathrm{H} 2 \mathrm{c}$ (effect on banking concentration and stability of the banking system) at all. For those, we do not find support for our hypotheses.

\subsubsection{Bank non-performing loans to total gross loans}

For our hypothesis that credit information sharing systems should reduce the percentage of non-performing loans, we are able to establish a sound regression model, and yet, the two determinants of interest here, PCR coverage and PCB coverage both remain insignificant consistently.

Dependent Variable: NPL

Number of obs $=1,035$, Number of groups $=124$, R-squared - overall $=0.0629$

Table 5. Results of the panel-regression with the dependent variable NPL

\begin{tabular}{|l|c|c|c|c|c|c|}
\hline \multicolumn{1}{|c|}{ Variable } & Coef. & $\begin{array}{c}\text { Robust } \\
\text { Std. Err. }\end{array}$ & $\mathrm{t}$ & $\mathrm{P}>$ ItI & \multicolumn{2}{c|}{ [95\% Conf. Interval] } \\
\hline PCR coverage & .0243851 & .0236888 & 1.03 & 0.305 & -.0225054 & .0712757 \\
\hline PCB coverage & .0269058 & .0167105 & 1.61 & 0.110 & -.0061716 & .0599832 \\
\hline DcreditPS & -.0398178 & .0344794 & -1.15 & 0.250 & -.1080676 & .0284321 \\
\hline Unemployment & .8247672 & .1792056 & 4.60 & 0.000 & .4700407 & 1.179494 \\
\hline GDP per capita & -.0000606 & .0001015 & -0.60 & 0.552 & -.0002615 & .0001404 \\
\hline GDP growth & -.1097572 & .0717523 & -1.53 & 0.129 & -.2517865 & .0322721 \\
\hline Boone & 2.79437 & 1.612031 & 1.73 & 0.086 & -.3965473 & 5.985286 \\
\hline IOEF & .1616508 & .2164847 & 0.75 & 0.457 & -.2668674 & .5901691 \\
\hline & & & & & \\
\hline 2006 & -.7552574 & .3286041 & -2.30 & 0.023 & -1.405709 & -.1048058 \\
\hline 2007 & -1.015312 & .5089121 & -2.00 & 0.048 & -2.022672 & -.0079518 \\
\hline 2008 & -1.940498 & .7678843 & -2.53 & 0.013 & -3.460477 & -.4205178 \\
\hline 2009 & -1.313513 & .7472642 & -1.76 & 0.081 & -2.792676 & .1656509 \\
\hline 2010 & -.6653035 & .8147368 & -0.82 & 0.416 & -2.278025 & .9474181 \\
\hline 2011 & -1.406535 & .9062277 & -1.55 & 0.123 & -3.200357 & .3872871 \\
\hline 2012 & -1.160394 & .9375516 & -1.24 & 0.218 & -3.01622 & .6954315 \\
\hline 2013 & -.8573481 & 1.00037 & -0.86 & 0.393 & -2.837519 & 1.122823 \\
\hline 2014 & -1.670183 & 1.023368 & -1.63 & 0.105 & -3.695878 & .3555116 \\
\hline Cons & -7.192776 & 12.23111 & -0.59 & 0.558 & -31.4035 & 17.01795 \\
\hline
\end{tabular}

Even when testing with lags of the dependent variable in an autoregressive model variant (the first few annual lags proved to be significant), both credit information sharing variables still turned out to be non-significant.

\subsubsection{Bank lending rate minus inflation rate and risk premium on lending}

Our assumption was that with the existence of credit information sharing systems, the risks for banks with (potential) borrowers declines and thus the real lending rate (deflated by the use of the consumer price index, to take into account different interest rates globally) resp. the RPOL should be able to stay lower. We kept a similar set of variables throughout the analysis in the paper for reasons of comparability and consistency, but we calculated a $\mathrm{R}^{2}$ below $1 \%$. We interpret that we are not able to explain our dependent variable with the given independent variables in any sufficient and satisfactory manner to be able to come up with meaningful results that would allow us to interpret the tests with a view on the hypothesis.

\subsubsection{Bank concentration and stability of the banking system}

There are numerous variables which can be used as a proxy for bank concentration (cp. appendix). As in the previous subchapter, we retrieved very small $\mathrm{R}^{2}$ values (below $1 \%$ ) and thus abstain from showing the results in a table. The same applies for the Z-Score. An exception exists for the lerner-index, where we calculated an $\mathrm{R}^{2}$ of $2.2 \%$, which we deem to still be too small to consider the results, and with non-significant values for the two information sharing coverage ratios. Therefore, we cannot test our hypothesis that credit information sharing leads to less bank concentration in a country. As argued by Rona-Tas (2015, p. 179), it seems to be reasonable that credit information sharing does not necessarily result in more stable markets. Several countries with a long tradition of credit reporting and full file information systems (using both, negative as well as 
positive information on consumers), seem to rank among the worst in relation to consumer debt amount. However, the simple amount may not show the full picture, as the distribution of debt among different classes is important as well. If poor consumers (or countries) add up even more debt, the situation may not be stable. Consequently, default problems seem to play a bigger role in poor countries. Four possible reasons seem to contradict a positive effect of credit reporting on stability: (1) Perverse effects: due to credit reporting, lending may increase, which may result in larger and riskier loans and new (riskier) borrowers entering the market, and overconfidence and relying (too) heavily on widely accepted automated tools; (2) Data quality resp. the social construction of data: some (negative) data may not be shared; errors may exist in the dataset, in highly concentrated markets, the big players have less incentive to share their data when data sharing is based on a voluntary process, and lenders who understand the scoring process might utilize this knowledge in their favor; (3) relational nature of lending: information asymmetry for both borrower and lenders may exist and should be solved, a borrower may not necessarily have more knowledge on his intention than lenders who may have a better understanding about the forces beyond the control or not foreseen by a borrower, as sickness or the economic development in a country, next, borrowing and repayment may not be entirely the business of the borrower but the actions taken by the lender, even if a loan is already granted, may be still important in the outcome (cp. about this point also Rona-Tas and Guseva, 2013, pp. 426-427); (4) endogeneity problem: Credit reporting systems based on past behavior have an outcome for future ones and may reward good behavior or sanction bad ones; and ultimately may result in vicious cycles, as they can influence a broad range of sectors. Giannetti et al. (2017), who focus on the public credit register show that banks manipulated their credit ratings by downgrading high quality and upgrading low quality borrowers before they shared their information. Such behavior may not only exist in the observed country and further limit the desired positive effects of credit information sharing as a whole.

\section{Conclusions}

The results for the financial inclusion part, where only data for the years 2011 and 2014 are available, should be seen as first, preliminary results on this issue and not be overrated. They indicate however, an empirically positive relationship between credit information sharing and financial inclusion (Account [at a financial institution], borrowing [from a financial institution], private credit / GDP). In total, these results seem to fit into the broader literature so far published about this topic. As new data on this issue will be published in 2018 , more research should be conducted, using this new data and the updated resp. improved data on the previous years.

There was more data available already now for the rest of our hypotheses tests (H1c through $\mathrm{H} 2 \mathrm{c})$, and we were able to run panel-regressions. However, we do not find significant results for an effect of credit reporting on non-performing loans and are not able to explain with our independent variables the effects on the real lending rate or bank concentration, as our $\mathrm{R}^{2}$ is too low.

Overall, there seems to be some evidence on the positive relationship between credit information sharing and financial inclusion. Even though some evidence was presented in other papers on banking related effects of credit reporting, we were not able to find them based on our dataset and suggested some explanations of why such an effect may occur in the first place. Alas, those may be dominated by other effects, such as overconfidence in these systems and the expansion of credit to customers not served before, which are probably riskier than the group of customers with a longer existing own credit history.

\section{References}

1. Akerlof, George A. (1970). The Market for "Lemons": Quality Uncertainty and the Market Mechanism. The Quarterly Journal of Economics, 84, (3), 488-500.

2. Ausubel, Lawrence M. (1999). Adverse Selection in the Credit Card Market, Working Paper, University of Maryland.

3. Behr, Patrick, Sonnekalb, Simon (2012). The effect of information sharing between lenders on access to credit, cost of credit, and loan performance - Evidence from a credit registry introduction, Journal of Banking \& Finance, 36, (11), 3017-3032.

4. Bennardo, Alberto, Pagano, Marco, Piccolo, Salvatore (2015). Multiple Bank Lending, Creditor Rights, and Information Sharing, in: Review of Finance, 19(2), 519-570.

5. Brown, Martin, Jappelli, Tullio, Pagano, Marco (2009). Information sharing and credit: Firm-level evidence from transition countries, in: Journal of Financial Intermediation, 18(2), 151-172. 
6. Brown, Martin, Zehnder, Christian (2010). The emergence of information sharing in credit markets, Journal of Financial Intermediation, 19(2), 255-278.

7. Bruhn, Miriam, Farazi, Subika, Kanz, Martin (2013). Bank Competition, Concentration, and Credit Reporting, Policy Research Working Paper, No. 6442, World Bank, Washington, D.C.

8. Büyükkarabacak, Berrak, Valev, Neven (2012). Credit information sharing and banking crises: An empirical investigation, Journal of Macroeconomics, 34(3), 788-800.

9. Cork, Kenneth (1982). Insolvency Law and Practice, Report of the Review Committee, Cmnd. 8558, London.

10. de Janvry, Alain, McIntosh, Craig, Sadoulet, Elisabeth (2010). The supply- and demand-side impacts of credit market information, Journal of Development Economics, 93(2), 173-188.

11. Djankov, Simeon, McLiesh, Caralee, Shleifer, Andrei (2007). Private credit in 129 countries, Journal of Financial Economics, 84(2), 299-329.

12. Fosu, Samuel (2014). Credit information, consolidation and credit market performance: Bank-level evidence from developing countries, International Review of Financial Analysis, 32, 23-36.

13. Giannetti, Caterina, Jentzsch, Nicola (2013). Credit reporting, financial intermediation and identification systems: International evidence, Journal of International Money and Finance, 33, 60-80.

14. Giannetti, Mariassunta, Liberti, Jose Maria, Sturgess, Jason (2017). Information Sharing and Rating Manipulation, Swedish House of Financial Research Paper, No. 15-11, Stockholm.

15. Gietzen, Thomas (2016). The Impact of Credit Information Sharing on Interest Rates, Swiss Institute of Banking and Finance (S/BF - HSG), Working Paper on Finance, No. 2016/12, University of St. Sallen.

16. Houston, Joel F., Lin, Chen, Lin, Ping, Ma, Yue (2010). Creditor rights, information sharing, and bank risk taking, Journal of Financial Economics, 96(3), 485-512.

17. Jaffee, Dwight M., Russell, Thomas (1976). Imperfect Information, Uncertainty, And Credit Rationing, Quarterly Journal of Economics, 90(4), 651-666.

18. Jappelli, Tullio, Pagano, Marco (2002). Information sharing, lending and defaults: Cross-country evidence, Journal of Banking \& Finance, 26(10), 2017-2045.

19. Klein, Daniel B. (1992). Promise keeping in the great society: a model of credit information sharing, Economics and Politics, 4(2), 117-136.

20. La Porta, Rafael, Lopez-De-Silanes, Florencio, Shleifer, Andrei (2008). The Economic Consequences of Legal Origin, Journal of Economic Literature, 46(2), 285-332.

21. Liu, Xian (2016). Methods and applications of longitudinal data analysis, Amsterdam et al.

22. Love, Inessa, Mylenko, Nataliya (2003). Credit Reporting and Financing Constraints, World Bank Policy Research Working Paper, No. 3142, Washington, D.C.

23. Luoto, Jill, McIntosh, Craig, Wydick, Bruce (2007). Credit Information Systems in Less Developed Countries: A Test with Microfinance in Guatemala, Economic Development and Cultural Change, 55(2), 313-334.

24. McIntosh, Craig,Wydick, Bruce (2005). Competition and Microfinance, Journal of Development Economics, 78(2), 271-298.

25. McIntosh, Craig, Wydick, Bruce (2009). What Do Credit Bureaus Do? Understanding Screening, Incentive, and Credit Expansion Effects, Working Paper, University of California, San Francisco.

26. Miller, Margaret J. (2003). Institutional Arrangements for Credit Reporting, in: Miller, Margaret J. (Ed.). Credit Reporting Systems and the International Economy, Cambridge, Massachusetts, 23-79.

27. Nana, P.V. Nketcha (2014). Legal rights, information sharing, and private credit: New cross-country evidence, The Quarterly Review of Economics and Finance, 54(3), 315-323.

28. Padilla, Jorge A., Pagano, Marco (1997). Endogenous Communication Among Lenders and Entrepreneurial Incentives, The Review of Financial Studies, 10(1), 205-236.

29. Padilla, Jorge. A., Pagano, Marco (2000). Sharing default information as a borrower discipline device, European Economic Review, 44(10), 1951-1980.

30. Pagano, Marco, Jappelli, Tullio (1993). Information Sharing in Credit Markets, The Journal of Finance, 48(15), 1693-1718.

31. Peria, Maria Soledad Martinez, Singh, Sandeep (2014). The Impact of Credit Information Sharing Reforms on Firm Financing, World Bank, Policy Research Working Paper, No. WPS7013, Washington, D.C.

32. Rona-Tas, Akos (2015). The Role of Credit Bureaus in Globalised Economies: Why They Matter Less Than We Think and How They Matter More, in: Micklitz, Hans-W., Domurath, Irina, (Eds.). Consumer Debt and Social Exclusion in Europe, London/New York, 177-187. 
33. Rona-Tas, Akos, Guseva, Alya (2013). Information and consumer credit in Central and Eastern Europe, Journal of Comparative Economics, 41, (2), 420-435.

34. Schmieder, Christian (2006). The Deutsche Bundesbank's Large Credit Database (BAKIS-M and MiMiK), Schmollers Jahrbuch, 126(4), 653-663.

35. Stiglitz, Joseph E., Weiss, Andrew (1981). Credit Rationing in Markets with Imperfect Information, The American Economic Review, 71(3), 393-410.

36. Vercammen, James A. (1995). Credit Bureau Policy and Sustainable Reputation Effects in Credit Markets, Economica, New Series, 62(248), 461-478.

37. White, Halbert (1980). A Heteroskedasticity-Consistent Covariance Matrix Estimator and a Direct Test for Heteroskedasticity, Econometrica, 48(4), 817-838.

38. World Bank - International Finance Corporation (2012). Credit Reporting Knowledge Guide, Washington, D.C.

39. World Bank - International Finance Corporation (2014). Doing Business 2015, Going Beyond Efficiency, 12th ed., Washington, D.C.

40. World Bank - International Finance Corporation (2015). Credit Reporting, http://www.ifc.org/wps/wcm/connect/Industry_EXT_Content/IFC_External_Corporate_Site/Industries/Financial+Markets/Financial+Infrastructure/Credit+Reporting/, 03.06.2017.

41. World Bank (2017). Doing Business, Getting Credit, http://www.doingbusiness.org/data/exploretopics/getting-credit, 18.06.2017.

\section{Appendix}

Table 1. Definitions and data sources of used variables

\begin{tabular}{|c|c|c|c|}
\hline Variable & Symbol & Definition & Data source \\
\hline \multicolumn{4}{|l|}{ Dependent Variables } \\
\hline 5-bank asset concentration & $5 \mathrm{BC}$ & $\begin{array}{l}\text { Assets of five largest banks as a share of total commercial } \\
\text { banking assets. Raw data are from Bankscope. }\end{array}$ & $\begin{array}{l}\text { World Bank: Global Fi- } \\
\text { nancial Development }\end{array}$ \\
\hline Account $(\%$ age $15+)$ & Account & $\begin{array}{l}\text { Percentage of respondents who report having an account (by } \\
\text { themselves or together with someone else) at a bank or an- } \\
\text { other type of financial institution. For } 2014 \text { this can be a } \\
\text { mobile account as well. }\end{array}$ & $\begin{array}{l}\text { World Bank: Global } \\
\text { Findex }\end{array}$ \\
\hline $\begin{array}{l}\text { Account at a financial insti- } \\
\text { tution }(\% \text { age } 15+)\end{array}$ & AccountFI & $\begin{array}{l}\text { Percentage of respondents who report having an account (by } \\
\text { themselves or together with someone else) at a bank or an- } \\
\text { other type of financial institution. }\end{array}$ & $\begin{array}{l}\text { World Bank: Global } \\
\text { Findex }\end{array}$ \\
\hline Bank concentration & $\mathrm{BC}$ & $\begin{array}{l}\text { Assets of three largest commercial banks as a share of total } \\
\text { commercial banking assets. Raw data are from Bankscope. }\end{array}$ & $\begin{array}{l}\text { World Bank: Global Fi- } \\
\text { nancial Development }\end{array}$ \\
\hline $\begin{array}{l}\text { Bank nonperforming loans } \\
\text { to total gross loans }(\%)\end{array}$ & NPL & $\begin{array}{l}\text { Value of nonperforming loans divided by the total value of } \\
\text { the loan portfolio (including nonperforming loans before the } \\
\text { deduction of specific loan-loss provisions). }\end{array}$ & $\begin{array}{l}\text { World Bank: World De- } \\
\text { velopment Indicators }\end{array}$ \\
\hline Bank Z-score & Z-Score & $\begin{array}{l}\text { It captures the probability of default of a country's commer- } \\
\text { cial banking system. Z-score compares the buffer of a coun- } \\
\text { try's commercial banking system (capitalization and returns) } \\
\text { with the volatility of those returns. }\end{array}$ & $\begin{array}{l}\text { World Bank: Global Fi- } \\
\text { nancial Development }\end{array}$ \\
\hline Boone indicator & Boone & $\begin{array}{l}\text { A measure of degree of competition based on profit-effi- } \\
\text { ciency in the banking market. It is calculated as the elasticity } \\
\text { of profits to marginal costs. An increase in the Boone indica- } \\
\text { tor implies a deterioration of the competitive conduct of fi- } \\
\text { nancial intermediaries. }\end{array}$ & $\begin{array}{l}\text { World Bank: Global Fi- } \\
\text { nancial Development }\end{array}$ \\
\hline $\begin{array}{l}\text { Borrowed from a financial } \\
\text { institution }(\% \text { age } 15+)\end{array}$ & BorrowedFI & $\begin{array}{l}\text { Percentage of respondents who report borrowing any money } \\
\text { from a bank or another type of financial institution in the past } \\
12 \text { months. }\end{array}$ & $\begin{array}{l}\text { World Bank: Global } \\
\text { Findex }\end{array}$ \\
\hline $\begin{array}{l}\text { Borrowers at a commercial } \\
\text { bank per } 1.000 \text { adults }\end{array}$ & BorrowersCB & $\begin{array}{l}\text { Calculated as: (number of borrowers with commercial banks) } \\
\text { x } 1.000 / \text { adult population in the reporting country. }\end{array}$ & $\begin{array}{l}\text { International Monetary } \\
\text { Fund: Financial Access } \\
\text { Survey }\end{array}$ \\
\hline $\begin{array}{l}\text { Domestic credit to private } \\
\text { sector }(\% \text { of GDP) }\end{array}$ & DcreditPS & $\begin{array}{l}\text { Financial resources provided to the private sector by financial } \\
\text { corporations, such as through loans, purchases of nonequity } \\
\text { securities, and trade credits and other accounts receivable, } \\
\text { that establish a claim for repayment. For some countries these } \\
\text { claims include credit to public enterprises. }\end{array}$ & $\begin{array}{l}\text { World Bank: World De- } \\
\text { velopment Indicators }\end{array}$ \\
\hline $\begin{array}{l}\text { Domestic credit to private } \\
\text { sector by banks (\% of GDP) }\end{array}$ & DcreditbyB & $\begin{array}{l}\text { Financial resources provided to the private sector by other de- } \\
\text { pository corporations (deposit taking corporations except cen- } \\
\text { tral banks), such as through loans, purchases of nonequity se- } \\
\text { curities, and trade credits and other accounts receivable, that } \\
\text { establish a claim for repayment. For some countries these } \\
\text { claims include credit to public enterprises. }\end{array}$ & $\begin{array}{l}\text { World Bank: World De- } \\
\text { velopment Indicators }\end{array}$ \\
\hline
\end{tabular}


Table 2 (cont.). Definitions and data sources of used variables

\begin{tabular}{|c|c|c|c|}
\hline Variable & Symbol & Definition & Data source \\
\hline H-statistic & H-Statistic & $\begin{array}{l}\text { A measure of the degree of competition in the banking mar- } \\
\text { ket. It measures the elasticity of banks revenues relative to in- } \\
\text { put prices. }\end{array}$ & $\begin{array}{l}\text { World Bank: Global Fi- } \\
\text { nancial Development }\end{array}$ \\
\hline $\begin{array}{l}\text { Lending minus inflation } \\
\text { rate }\end{array}$ & LMI & $\begin{array}{l}\text { Own calculation: Lending interest rate }(\%) \text { - inflation, con- } \\
\text { sumer prices (annual } \%) \text {. Whereas lending rate is the bank rate } \\
\text { that usually meets the short-and medium-term financing } \\
\text { needs of the private sector. }\end{array}$ & $\begin{array}{l}\text { World Bank: World De- } \\
\text { velopment Indicators }\end{array}$ \\
\hline Lerner index & Lerner & $\begin{array}{l}\text { A measure of market power in the banking market. It compares } \\
\text { output pricing and marginal costs (that is, markup). An increase } \\
\text { in the Lerner index indicates a deterioration of the competitive } \\
\text { conduct of financial intermediaries. Calculated from underlying } \\
\text { bank-by-bank data from Bankscope. }\end{array}$ & $\begin{array}{l}\text { World Bank: Global Fi- } \\
\text { nancial Development }\end{array}$ \\
\hline $\begin{array}{l}\text { Risk premium on lending } \\
\text { (lending rate minus treasury } \\
\text { bill rate, } \% \text { ) }\end{array}$ & RPOL & $\begin{array}{l}\text { Interest rate charged by banks on loans to private sector cus- } \\
\text { tomers minus the "risk free" treasury bill interest rate at which } \\
\text { short-term government securities are issued or traded in the } \\
\text { market. }\end{array}$ & $\begin{array}{l}\text { World Bank: World De- } \\
\text { velopment Indicators }\end{array}$ \\
\hline \multicolumn{4}{|l|}{ Independent Variables } \\
\hline Boone indicator & Boone & $\begin{array}{l}\text { A measure of degree of competition based on profit-effi- } \\
\text { ciency in the banking market. It is calculated as the elasticity } \\
\text { of profits to marginal costs. An increase in the Boone indica- } \\
\text { tor implies a deterioration of the competitive conduct of fi- } \\
\text { nancial intermediaries. }\end{array}$ & $\begin{array}{l}\text { World Bank: Global Fi- } \\
\text { nancial Development }\end{array}$ \\
\hline $\begin{array}{l}\text { Branches of commercial } \\
\text { banks per } 100.000 \text { adults }\end{array}$ & BranchesCB & $\begin{array}{l}\text { Calculated as: (number of commercial banks }+ \text { number of com- } \\
\text { mercial bank branches) x 100.000/adult population in the report- } \\
\text { ing country. }\end{array}$ & $\begin{array}{l}\text { International Monetary } \\
\text { Fund: Financial Access } \\
\text { Survey }\end{array}$ \\
\hline $\begin{array}{l}\text { Domestic credit to private } \\
\text { sector }(\% \text { of GDP) }\end{array}$ & DcreditPS & $\begin{array}{l}\text { Financial resources provided to the private sector by financial } \\
\text { corporations, such as through loans, purchases of nonequity } \\
\text { securities, and trade credits and other accounts receivable, } \\
\text { that establish a claim for repayment. For some countries these } \\
\text { claims include credit to public enterprises. }\end{array}$ & $\begin{array}{l}\text { World Bank: World Devel- } \\
\text { opment Indicators }\end{array}$ \\
\hline GDP growth (annual \%) & GDP growth & $\begin{array}{l}\text { Annual percentage growth rate of GDP at market prices based } \\
\text { on constant local currency. Aggregates are based on constant } \\
2010 \text { U.S. dollars. }\end{array}$ & $\begin{array}{l}\text { World Bank: World Devel- } \\
\text { opment Indicators }\end{array}$ \\
\hline $\begin{array}{l}\text { GDP per capita (constant } \\
2010 \text { US\$) }\end{array}$ & GDP per capita & $\begin{array}{l}\text { Gross domestic product divided by midyear population. GDP } \\
\text { is the sum of gross value added by all resident producers in } \\
\text { the economy plus any product taxes and minus any subsidies } \\
\text { not included in the value of the products. }\end{array}$ & $\begin{array}{l}\text { World Bank: World Devel- } \\
\text { opment Indicators }\end{array}$ \\
\hline $\begin{array}{l}\text { Index of Economic Free- } \\
\text { dom }\end{array}$ & IOEF & $\begin{array}{l}\text { The score focuses on four key aspects of the economic envi- } \\
\text { ronment: rule of law, government size, regulatory efficiency, } \\
\text { market openness and assesses them by twelve specific com- } \\
\text { ponents of economic freedom. }\end{array}$ & Heritage Foundation \\
\hline Legal Origin & $\begin{array}{l}\text { eng, french, ger, scan, } \\
\text { soc }\end{array}$ & $\begin{array}{l}\text { Legal historic tradition in a country and on which kind of law it is } \\
\text { rooted. }\end{array}$ & $\begin{array}{l}\text { Djankov et al. (2007), La } \\
\text { Porta et al. (2008), CIA: The } \\
\text { World Factbook }\end{array}$ \\
\hline Lending minus inflation rate & LMI & $\begin{array}{l}\text { Own calculation: Lending interest rate (\%) - inflation, con- } \\
\text { sumer prices (annual } \%) \\
\text { Whereas lending rate is the bank rate that usually meets the } \\
\text { short-and medium-term financing needs of the private sector. }\end{array}$ & $\begin{array}{l}\text { World Bank: World Devel- } \\
\text { opment Indicators }\end{array}$ \\
\hline $\begin{array}{l}\text { Population density (people } \\
\text { per sq. km of land area) }\end{array}$ & Popdensity & Midyear population divided by land area in square kilometers. & $\begin{array}{l}\text { World Bank: World Devel- } \\
\text { opment Indicators }\end{array}$ \\
\hline $\begin{array}{l}\text { Private credit bureau cover- } \\
\text { age ( } \% \text { of adults) }\end{array}$ & PCB coverage & $\begin{array}{l}\text { Number of individuals or firms covered by a private credit bureau } \\
\text { with information on their repayment history, unpaid debts, or } \\
\text { credit outstanding from the past } 5 \text { years. }\end{array}$ & $\begin{array}{l}\text { World Bank: Doing } \\
\text { Business }\end{array}$ \\
\hline $\begin{array}{l}\text { Public credit registry cover- } \\
\text { age ( } \% \text { of adults) }\end{array}$ & PCR coverage & $\begin{array}{l}\text { Number of individuals or firms covered by a public credit registry } \\
\text { with information on their repayment history, unpaid debts, or } \\
\text { credit outstanding from the past } 5 \text { years. }\end{array}$ & $\begin{array}{l}\text { World Bank: Doing } \\
\text { Business }\end{array}$ \\
\hline $\begin{array}{l}\text { Unemployment, total (\% } \\
\text { of total labor force) }\end{array}$ & Unemployment & $\begin{array}{l}\text { Unemployment refers to the share of the labor force that } \\
\text { is without work but available for and seeking employ- } \\
\text { ment. Based on International Labour Organization data. }\end{array}$ & $\begin{array}{l}\text { World Bank: World De- } \\
\text { velopment Indicators }\end{array}$ \\
\hline
\end{tabular}

The table provides definitions and data sources for all the variables that are used in the regressions.

\section{Table 2. Summary statistics for regression 1 and 2}

The table presents descriptive statistics for the data used in the regression. Data are rounded on the second decimal point position. Further variable definitions and data sources are provided in Appendix Table 1. 


\begin{tabular}{|c|c|c|c|c|c|c|c|}
\hline Variable & Exp. Influence & Symbol Obs. & Mean & Median & Std. dev. & Min. & Max. \\
\hline \multicolumn{8}{|l|}{ Dependent variable } \\
\hline Account & & 156 & 49.73 & 41.77 & 31.05 & 1.10 & 100.00 \\
\hline AccountFI & & 156 & 48.89 & 41.77 & 31.69 & 1.10 & 100.00 \\
\hline BorrowedFI & & 156 & 10.94 & 10.56 & 6.56 & 0.67 & 31.11 \\
\hline BorrowersCB & & 101 & 198.28 & 136.46 & 221.60 & 1.34 & 1100.88 \\
\hline \multicolumn{8}{|c|}{ Independent variable } \\
\hline BranchesCB & + & 185 & 19.68 & 13.10 & 25.66 & 0.69 & 256.15 \\
\hline GDP growth & + & 195 & 3.46 & 3.75 & 5.70 & -62.08 & 24.10 \\
\hline GDP per capita & + & 195 & 13606.52 & 5386.96 & 19216.95 & 219.01 & 103756.20 \\
\hline IOEF & + & 180 & 59.93 & 60.10 & 11.59 & 1.00 & 89.90 \\
\hline \multicolumn{8}{|l|}{ Legal Origin } \\
\hline eng & $-1+$ & 186 & 0.34 & 0.00 & 0.48 & 0.00 & 1.00 \\
\hline french & $-1+$ & 186 & 0.46 & 0.00 & 0.50 & 0.00 & 1.00 \\
\hline ger & $-1+$ & 186 & 0.10 & 0.00 & 0.30 & 0.00 & 1.00 \\
\hline soc & $-1+$ & 186 & 0.07 & 0.00 & 0.26 & 0.00 & 1.00 \\
\hline PCB coverage & + & 189 & 26.34 & 3.95 & 35.45 & 0.00 & 100.00 \\
\hline PCR coverage & + & 189 & 9.28 & 0.00 & 17.28 & 0.00 & 93.10 \\
\hline Popdensity & + & 217 & 418.08 & 85.33 & 1916.15 & 0.14 & 18703.00 \\
\hline Unemployment & - & 175 & 8.66 & 7.05 & 6.03 & 0.35 & 31.05 \\
\hline
\end{tabular}

Table 3. Summary statistics for panel regression

The table presents descriptive statistics for the data used in the regression. Data are rounded on the second decimal point position. Further variable definitions and data sources are provided in Appendix Table 1.

\begin{tabular}{|c|c|c|c|c|c|c|c|c|c|c|c|}
\hline \multirow{2}{*}{$\begin{array}{l}\quad \text { Variable } \\
\text { Dependent } \\
\text { variable }\end{array}$} & \multicolumn{5}{|c|}{ Exp. Influence } & Symbol Obs. & Mean & Median & Std. dev. & Min. & Max. \\
\hline & & & & & & & & & & & \\
\hline $5 \mathrm{BC}$ & $*$ & & & & & 1252.00 & 81.23 & 84.65 & 17.20 & -0.14 & 100.00 \\
\hline $\mathrm{BC}$ & $*$ & & & & & 1491.00 & 71.93 & 72.71 & 19.90 & 2.78 & 100.00 \\
\hline Boone & $*$ & & & & & 1612.00 & -0.07 & -0.05 & 0.16 & -2.00 & 1.64 \\
\hline DcreditbyB & & $*$ & & & & 1957.00 & 49.71 & 38.08 & 42.23 & 0.42 & 312.15 \\
\hline DcreditPS & & $*$ & & & & 1956.00 & 52.53 & 39.16 & 45.38 & 0.43 & 312.15 \\
\hline H-Statistic & $*$ & & & & & 593.00 & 0.57 & 0.59 & 0.25 & -0.67 & 1.71 \\
\hline Lerner & $*$ & & & & & 1196.00 & 0.28 & 0.28 & 0.13 & -0.59 & 0.94 \\
\hline LMI & & & & $*$ & & 1531.00 & -9.52 & 5.68 & 609.49 & -23832.07 & 62.62 \\
\hline NPL & & & $*$ & & & 1469.00 & 6.46 & 3.93 & 7.10 & 0.01 & 59.76 \\
\hline RPOL & & & & $*$ & & 865.00 & 7.21 & 4.92 & 14.03 & -6.43 & 330.19 \\
\hline Z-score & & & & & $*$ & 1761.00 & 11.71 & 9.81 & 8.27 & -12.61 & 66.10 \\
\hline $\begin{array}{l}\text { Independent } \\
\text { variable }\end{array}$ & & & & & & & & & & & \\
\hline BranchesCB & & + & & & & 1951.00 & 19.64 & 12.88 & 26.74 & 0.24 & 289.83 \\
\hline Boone & & & $-1+$ & & & 1612.00 & -0.07 & -0.05 & 0.16 & -2.00 & 1.64 \\
\hline DcreditPS & & & + & & - & 1956.00 & 52.53 & 39.16 & 45.38 & 0.43 & 312.15 \\
\hline GDP growth & $-1+$ & + & - & - & + & 2146.00 & 3.88 & 3.80 & 5.06 & -62.08 & 36.52 \\
\hline GDP per capita & $-1+$ & + & - & - & + & 2124.00 & 13455.55 & 4829.36 & 19310.98 & 205.07 & 145221.0 \\
\hline IOEF & - & + & - & - & + & 2053.00 & 59.90 & 59.60 & 11.39 & 1.00 & 90.10 \\
\hline LMI & & - & & & & 1531.00 & -9.52 & 5.68 & 609.49 & -23832.07 & 62.62 \\
\hline PCB coverage & - & + & - & - & + & 2212.00 & 23.51 & 0.00 & 34.16 & 0.00 & 100.00 \\
\hline PCR coverage & - & + & - & - & + & 2212.00 & 7.79 & 0.00 & 16.39 & 0.00 & 100.00 \\
\hline Popdensity & $-1+$ & & & - & & 2387.00 & 404.94 & 82.78 & 1849.44 & 0.14 & 19392.94 \\
\hline Unemployment & $-1+$ & - & + & + & - & 1750.00 & 8.54 & 7.00 & 6.09 & 0.10 & 37.60 \\
\hline
\end{tabular}

